\title{
Geological investigation of river terraces along the Modi Khola valley, Parbat district, western Nepal Lesser Himalaya
}

\author{
Sudip Lamsal, Nabaraj Sapkota, Arjun Bhandari, Ishor Gyanwali, Kabi Raj Paudyal, and *Lalu Paudel \\ Central Department of Geology, Tribhuvan University, Kirtipur, Kathmandu, Nepal \\ *(Corresponding email: lalupaudel67@yahoo.com)
}

\begin{abstract}
Fluvial terraces are remnants of the former floodplain of a stream or river. Wide river valley with spectacular terraces are the well-known places of the Himalaya because of their unique morphology and history of origin. The Modi Khola and Kali Gandaki valleys in west Nepal, Lesser Himalaya are characterized by a number of spectacular river terraces. In the present study, the river terraces along the Modi Khola valley were mapped at 1:25,000 scale and their lithological and sedimentological characteristics were investigated. The river terraces along the Modi Khola are distributed in at least three levels. They are named as Godam Formation (Higger Terrace), Badagaun Formation (Middle Terrace) and the Modibeni Formation (Lower Terrace). The Godam Formation is standing out at an elevation between $860 \mathrm{~m}$ and $1100 \mathrm{~m}$. The upper surface of the terrace is extremely rugged with karstic features. The Godam Formation is characterized by matrix-supported, calcite cemented conglomerate with angular to sub-angular clasts of calcareous shale, laminated siliceous limestone and quartzite. The Badagaun Formation (Middle Terrace) is distributed at an altitude from 700 to $860 \mathrm{~m}$ on both sides of the Modi Khola valley. It is deeply weathered forming a very thick (almost 3-5 m) residual soil (mostly lateritic soil). Karst features such as caves and sink holes are common in this terrace. This formation is mainly composed of matrix-supported conglomerate with granule-, cobble- and boulder-sized clasts of calcareous shale, siliceous limestone and rarely quartzite. The Lower Terrace (Modibeni Formation) is fluvial deposit consisting of rounded and subrounded clast-supported conglomerate. Both the Upper and Middle Terraces have been interpreted as cohesive debris flow facies derived from the Annapurna Range. Presence of three levels of terraces indicates at least three phase of uplift in the area in the Holocene time. The debris flow deposit in the upper and Middle Terraces indicates catastrophic outbursts from natural dams or large rock-ice avalanches in the Annapurna Range triggered probably by megaearthquakes as in Pokhara valley as suggested by Schwanghart et al. (2015).
\end{abstract}

Keywords: River terrace, karst landforms, Modi Khola, Lesser Himalaya, Quaternary geology

Received: November 2016

Revision accepted: 19 March 2017

\section{INTRODUCTION}

Fluvial terraces are remnants of the former floodplain of a stream or river. They are formed by the downcutting of a river or stream channel into and the abandonment and lateral erosion of its former floodplain. The downcutting, abandonment, and lateral erosion of a former floodplain can be the result of either changes in sea level, local or regional tectonic uplift; changes in local or regional climate; changes the amount of sediment being carried by the river or stream; change in discharge of the river; or a complex mixture of these and other factors. The most common sources of the variations in rivers and streams that create fluvial terraces are vegetative, geomorphic, and hydrologic responses to climate. Terraces can be formed in many ways and in several geologic and environmental settings. By studying the size, shape, and age of terraces, one can determine the geologic processes that formed them. When terraces have the same age and/or shape over a region, it is often indicative that a large-scale geologic or environmental mechanism is responsible. Tectonic uplift and climate change are viewed as dominant mechanisms that can shape the earth's surface through erosion. River terraces can be influenced by one or both of these forcing mechanisms and therefore can be used to study variation in tectonics, climate, and erosion, and how these processes interact.

Wide river valley with spectacular terraces is the well-known places of the Himalaya because of their unique morphology and history of origin. It has been considered that these river terraces are the results of catastrophic debris flows during Quaternary Period (Sharma 1980; Yamanaka et al. 1982; Iwata 1982; 1984). Most of these valleys have been utilizing for the purpose of urban development as well for agricultural production. The Modi Khola and Kali Gandaki valleys in west Nepal (Fig. 1). The river terraces are characterized by recent landforms with nearly vertical cliff and sharp edges. Kusma (headquater of Parbat District) and Baglung (headquater of Baglung District) are situated on these river terraces. Although the presence of river terraces have been noted by many geologists in the past (see the following section), geological mapping and sediment logical studies of these terraces are still lacking. Present work is aimed at mapping of river terraces along the Modi Khola valley at 1:25,000 scale, preparation of columnar section and carrying out sedementological analysis. This work will provide a basis for understanding the Quaternary geological history of the area. 


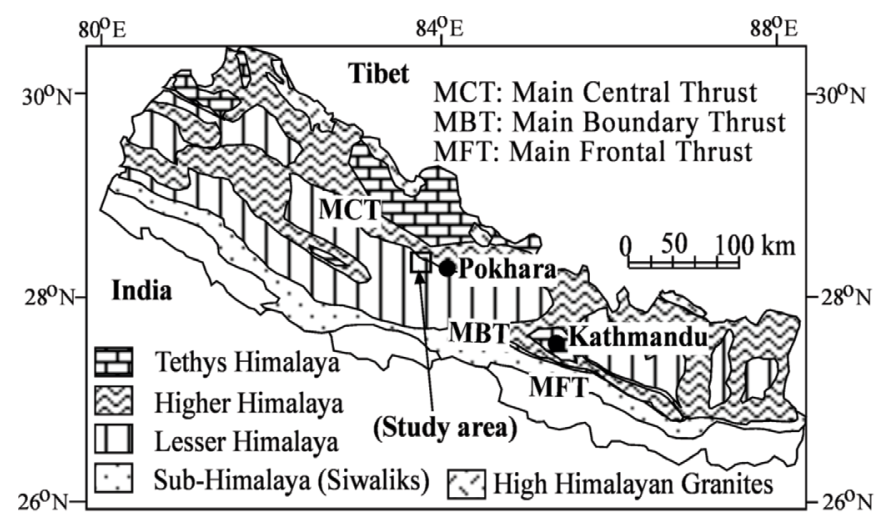

Fig. 1: Generalized tectonic map of the Nepal Himalaya showing the location of the present study area (modified after Upreti 1999).

\section{PREVIOUS STUDIES}

Early investigations by Hagen (1969), Gurung (1970), and Sharma (1975) made a first report of occurrence of Quaternary river terraces in the Pokhara and adjacent areas. Hormann (1974) classified various terraces of the Pokhara valley. Fort (1976) made a short description of the Quaternary geology of the middle Kali Gandaki valley and noted three types of sedimentation basins in the Kali Gandaki valley. These are (i) Kusma type, a mainly coarsely alluvial basin; (ii) Ghasa type, a complex basin, with alluvial, torrential and morainic facies; and (iii) Thakkhola type, showing mainly lacustrine and alluvial deposits. Present study area belongs to the KusmaBaglung basin of Fort (1976). She identified five geomorphic levels in the area. Level (5) is the highest one developed on bed rock, level (4) is pediment-terrace developed in conglomerate, level (3) represents probably a fill-cut terrace developed within level (4), levels (2) and (1) are alluvial terraces made of unconsolidated and recent. She considers the level (4) and (3) sediments as mudflows or debris flows.

Sharma (1980) described the origin of Quaternary deposits of Nepal and their neo-tectonic significance. He suggested that the origin of the river terraces in the Kali Gandaki, Modi Khola, Seti River is controlled by Himalayan tectonism. The river terraces of the Kali Gandaki between Behadi and Kusma (south of Kusma) were studied by Sharma et al. (1980). They classified them into the T1 standing out from 300 to $400 \mathrm{~m}$ from river bed, T2 lying at 25 to $60 \mathrm{~m}$ from river bed, and T3 between 10-15 $\mathrm{m}$ from the river bed. They inferred that the large the T1 and T2 were fluvio-glacial accumulations, derived from the Great Himalayan Range and accumulated in lakelike stagnant water, caused by damming of the river during the upheaval of the Mahabharat Range.

Yamanaka and Iwata (1982) studied the river terraces of the Kali Gandaki between Beni and Setibeni. They divided the river terraces into the Higher, Middle, and Lower Terraces. The Higher Terrace is distributed between Beni and Balewa. It is a filltop terrace made up of more than 300 thick conglomerates and its base is situated below the riverbed. The Middle
Terraces are found between Baglung and Setibeni. They contain conglomerates of subangular to subrounded cobbles and boulders of limestone, gneiss, schist, and quartzite. There also occur a few extremely hardened conglomerate beds with calcareous matrix. The Lower Terraces represented by fillstrath terrace carved in the younger valley fill deposits. Iwata and Nakata (1985) investigated the river terraces of the Kali Gandaki in its lower reach around Narayangarh. They identified 13 terrace levels, and divided them into 6 groups. Yamanaka (1982) carried out radiocarbon dating of Pokhara Formation and interpreted that the gravels of Pokhara Formation were catastrophically emplaced only 500 to 1000 years ago, although the exact nature, timing, and triggers of the purported event(s) remained obscure. The ages also suggest that the Pokhara Formation was accumulated very rapidly within a few hundred years. Yamanaka (1982) also carried out radiocarbon dating of a wood piece from river terrace of the Modi Khola at Birethanti. The age of sample was determined to be $1,000+100$ yr BP. The age of this mudflow deposit coincides well with that of the Pokhara Formation.

Fort and Freytet (1983) carried out morphological and sedimentological studies of the intermontane basin of Pokhara and interpreted the sedimentary evolution. They tried to correlate the breccia deposit (1B) of the Pokhara area with that of the level 3 breccia of Kusma area. They argue that both the basins entertained independent evolution. Fort (1985) refers the glacio-fluvial deposit of the Pokhara valley as a result of cooling of climate specially in the high mountain range. The river terraces of the Pokhara valley have been recently studied by Schwanghart et al. (2014 and 2015). According to them the gravels of the Pokhara Formation represent poorly sorted, gravelly fluvial facies intercalated with debris-flow and mudflow facies. They attest to highly energetic transport conditions during one or several catastrophic flow events following at least three medieval earthquakes in the Nepal Himalayas. Radiocarbon dates from peat beds, plant macrofossils, and humic silts in fine-grained tributary sediments near Pokhara, match the timing of nearby $\mathrm{M}>8$ earthquakes in $\sim 1100,1255$, and 1344 C.E.

\section{MATERIALS AND METHOD}

The methods used in the present research are presented in four broad topics namely (i) desk study, (ii) field study, (iii) laboratory analysis, (iv) data synthesis and interpretation. At first the relevant literature related to the present study were reviewed. Published geological maps and cross sections of the present area were carefully observed to know about the tectonic setting of the area. Distribution of the river terraces in the area were identified by observing the Google Earth Satellite Images. Geological mapping of the river terrace were carried out at 1:25,000 scale topographic base maps. Geological compass, hammer, altimeter and GPS were used for mapping.

Delineation of terrace deposits was based on their relative height above the modern channel, using eye-height methods 
and GPS surveying. Map unit names for the terrace deposits were decided according to the geographic names where the corresponding terraces can be best observed. For the establishment of the lithostratigraphy of each terrace, vertical sections were selected at different parts of the valley and detailed columnar sections were prepared. Additionally lithofacies were also described according to the overall texture and compositional variation of conglomerate. The identification of each lithofacies model and interpretation of sedimentary depositional environment were performed according to the lithofacies model developed by Miall (1996). For the analysis of average grain size and the composition of the clast distribution in the middle and higher terrace level, the clast count was performed from different locations. The percentage of clast and matrix was also identified by measuring the proportion of matrix and clast from the scan line of $1 \mathrm{~m}$ in conglomerate exposure.

Samples were collected for the grain size and textural analysis. Samples of bedrock and big boulders in the sediments were collected for the petrographic study. The fine sediment samples were also studied under the binocular microscope to know the composition and texture of the sediments. Finally maps, cross sections and all necessary drawings were prepared. The data were interpreted and synthesized to understand the geological evolution of the area.

\section{RESULTS}

In the study area, the river terraces are distributed at the bank of the Modi Khola forming the steep cliff along the river valleys and flat land on the top. The height of the river terrace ranges from $10 \mathrm{~m}$ to $380 \mathrm{~m}$ above present river bed. The lithostratigraphy and sedimentological characteristics of the terraces are given the following sections.

\section{Lithostratigraphy of the Quaternary Deposit}

At least three prominently developed river terraces are observed along the Modi Khola valley between Gijan and Modibeni (Fig. 2). The highest terrace is geologically oldest and the lowest terrace is geologically youngest. The Upper Terrace is named as the Godam Formation, Middle Terrace is named as the Badagaun Formation and the Lower Terrace is named as the Modibeni Formation (Figs. 3, 4 and 5). The characteristics of each terrace have been described in the following section.

\section{Godam Formation (Upper Terrace)}

The Upper Terrace is named after the village Godam, north of Kusma where the sediments are well exposed. The Upper Terrace is distributed at the altitude from 860 to $1100 \mathrm{~m}$. It is found at Godam, Chuwa, Gijan and Thum along both sides of the Modi Khola valley. Mostly the Upper Terraces are unpaired. It occurs as randomly dispersed small patches of hillocks and barren rocks. The terrace is deeply weathered and strongly eroded to form deep gullys and channels. Red residual soil is developed on top of the terraces. The upper surface of the terrace is extremely rugged with karstic features.

A generalized columnar section of the upper part of the Godam Formation is given in Fig. 5. Maximum thickness of the formation is about $240 \mathrm{~m}$ measured from the boundary of lower and Middle Terrace. However, the exposed thickness varies from place to place due to variation in erosion. The lowermost part of this formation is characterized by the light grey, matrix supported, calcite cemented conglomerate with angular to sub-angular clasts calcareous shale, calcareous phyllite, laminated siliceous limestone and quartzite (Fig. 6). In the middle part it this formation it is characterizes by predominantly coarser size clast ranges from pebble to boulder, angular to sub-angular clast of quartzite, calcareous shale. The conglomerate is strongly cemented with sparry calcite (Fig. 7). It is mostly unstratified and poorly sorted. The clast-matrix ratio is almost $1: 1$. Clasts are mostly angular and range in size from a few centimeter to a meter.

\section{Badagaun Formation (Middle Terrace)}

The Modi Khola valley is mostly covered by the Middle Terrace. It is well-exposed in the Badagaun area and is named as Badagaun Formation. It is distributed at the altitude from 700 to $860 \mathrm{~m}$. The Middle Terrace is found at Gijan, Pakuwa, Silmi, Chuwa, Katuwa Chaupari, Khareha, Kusma and Badagaun areas along both sides of the Modi Khola valley. The terraces are mostly paired except in some places. Most of the flat and cultivated land lies on the Middle Terrace. It is deeply weathered forming a very thick (almost 3-5 m) residual soil (mostly lateritic soil). Karst features such as caves and sink holes are common in this terrace. The Gupteshowr Cave of Kusma and the Alapeshowor Cave of Katuwa Chaupari are some examples. Small underground channels and cavities are abundant in this terrace.

A generalized columnar section of the Badagaun Formation is given in Fig. 8. This formation is about 150 to $160 \mathrm{~m}$ thick. The lithology of this formation is uniform around the study area. This formation is mainly composed of matrix-supported conglomerate with granule-, cobble- and boulder-sized clasts of calcareous shale, laminated siliceous limestone and quartzite (Fig. 9). The matrix is fine-grained mud and silt size fraction. It the conglomerate is strongly cemented by calcite.

\section{Modibeni Formation (Lower Terrace)}

It forms the newly developed lowermost terrace with the distinctly visible fluvial deposit. The average thickness of this terrace ranges from $5-20 \mathrm{~m}$ from the river channel. It is characterized by unconsolidated deposits of clast-supported gravel (Fig. 10). It is mainly composed of the rounded to sub rounded, pebble to boulder size clasts of quartzite, gneiss, metasandstone, shale, marble, amphibolites and also some of the ferruginous rocks. The sediments distinctly show upward fining cycle of sediments and some imbrications of gravels (Fig. 11). The matrix is sand and silt. 


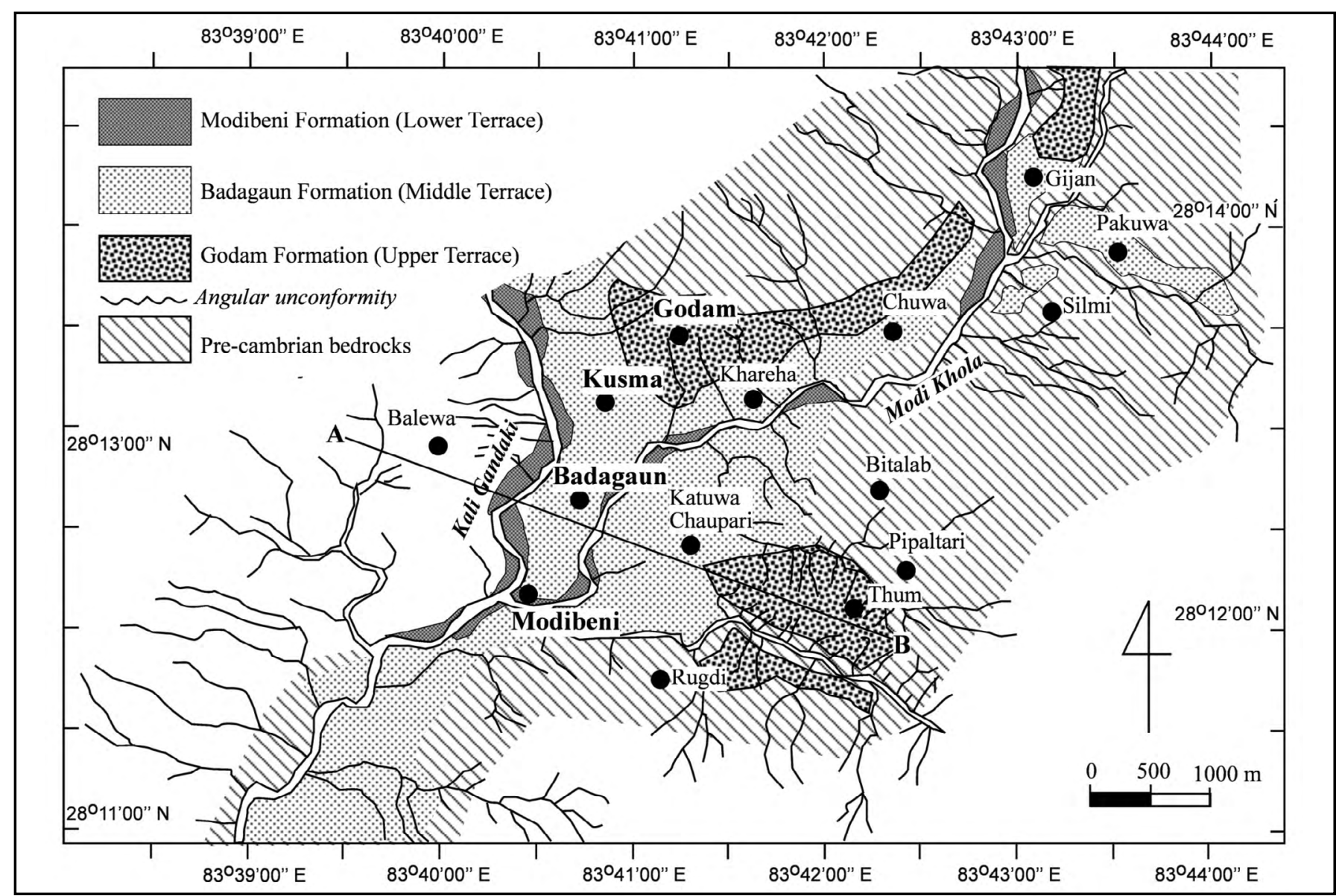

Fig. 2: Geological map of the Modi Khola valley between Gijan and Modibeni showing the distribution of river terraces and bedrocks. A-B: Line of cross-section in Fig. 3.

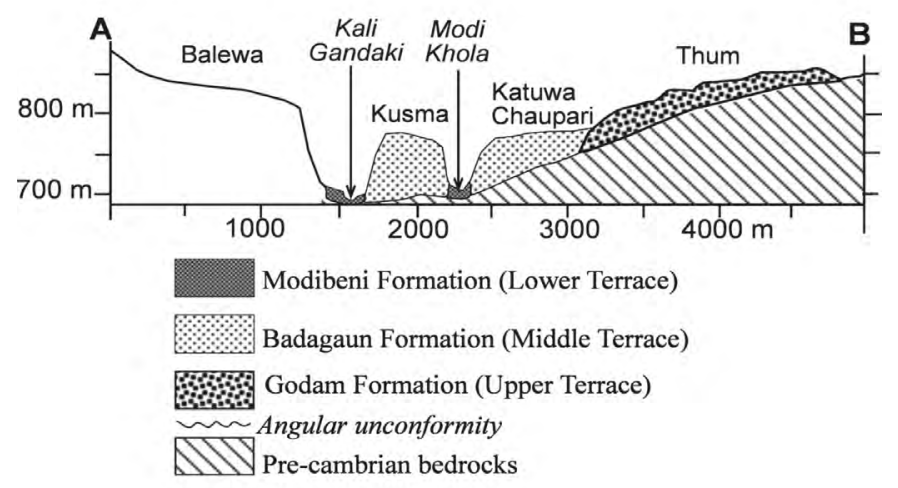

Fig. 3: Geological cross section along A-B (see Fig. 2) showing the distribution of terraces at different elevations.

\section{Lithofacies, depositional environment and provenance}

This part represents the interpretation of sediments in terms of processes of transport and deposition and their sedimentary environments. The lithofacies analysis of the river terrace deposits was performed from the different section and tried to categorize according to the overall compositional variation, texture and sedimentary structure. Major lithofacies types are Gmm and Gci according to classification by Mial (1978). $\mathrm{Gmm}$ is the most frequently observed lithofacies of the middle and upper river terrace of the study area. It is characterized

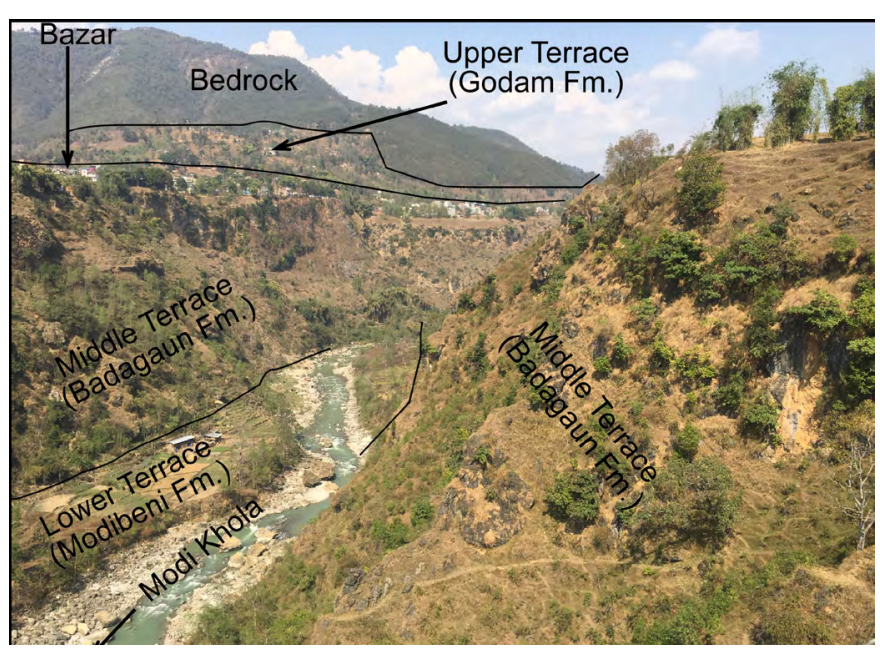

Fig. 4: Field photograph showing the three levels of river terraces observed along the Modi Khola valley, Parbat District. Photo viewing upstream along the Modi Khola from suspension bridge connecting Kusma and Katuwa Chaupari.

by poorly sorted clasts, strongly disorganized, structureless deposit with angular to subangular clasts surrounded by fine calcareous matrix. The grain size ranges from $2 \mathrm{~mm}$ to 190 $\mathrm{mm}$. The overall characteristics of the sediments in the Middle and Upper Terrace suggest a high-strength (cohesive) debris flow deposition. The Lower Terrace (Modibeni Formation) 


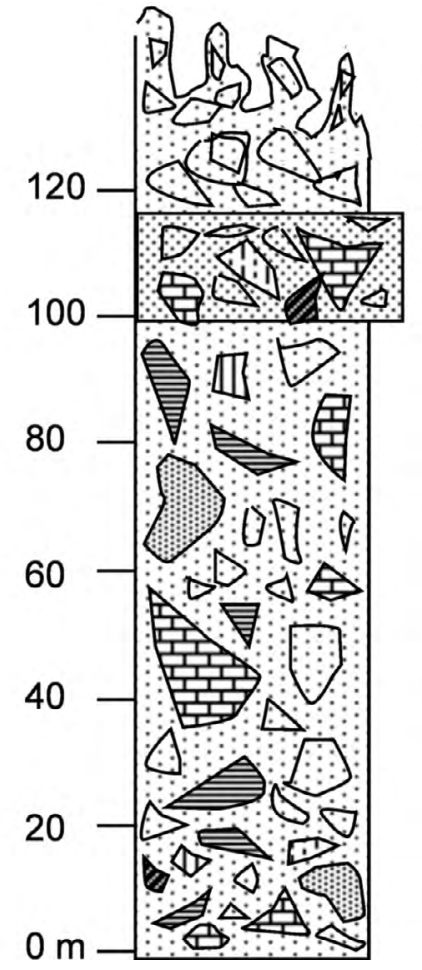

Extensively dissolved conglomerate with various karst features

Middle part dominated by big boulders of limestone and calcareous shale

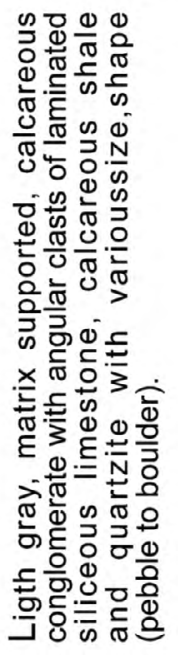

Fig. 5: Columnar section of the Godam Formation (Upper Terrace) at Godam, north of Kusma.

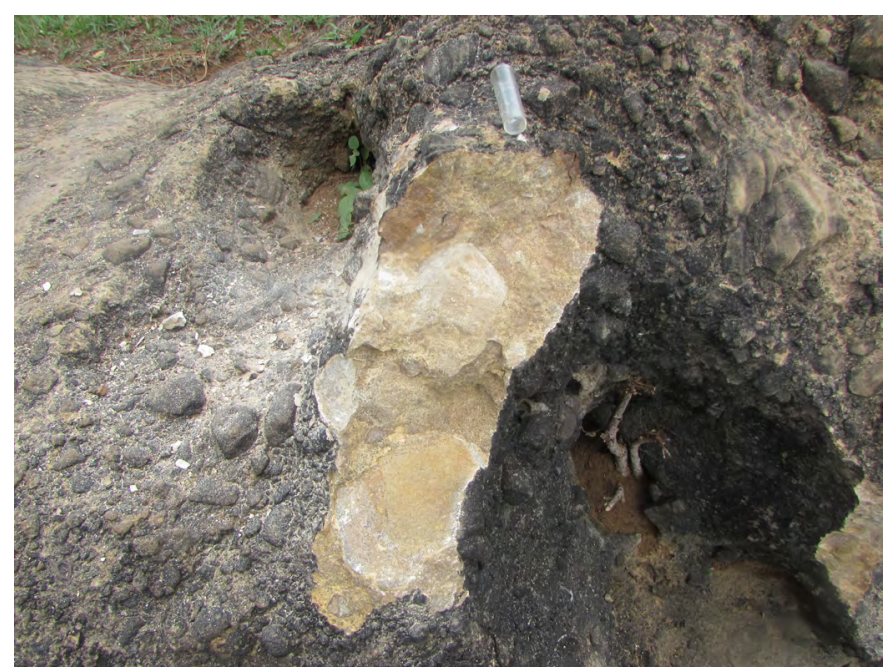

Fig. 6: Photograph of the upper part of the Godam Formation (Upper Terrace) at Katuwachaupari. The Godam Formation is strongly weatherd and express rugged topography with randomly dispersed hillocks of conglomerate. The conglomerate is matrix supported, clasts are mostly angular and it is strongly cemented with calcite and dolomite.

is identified as the lithofacies Gci. It is represented by clastsupported conglomerate with aungular to sub-angular clast of quartzite, calcareous shale, amphibolites and gneiss with fine calcareous matrix. The characteristics of Modibeni Formation suggest fluvial environment of depositon. It is channel fill or longitudinal bar deposit.

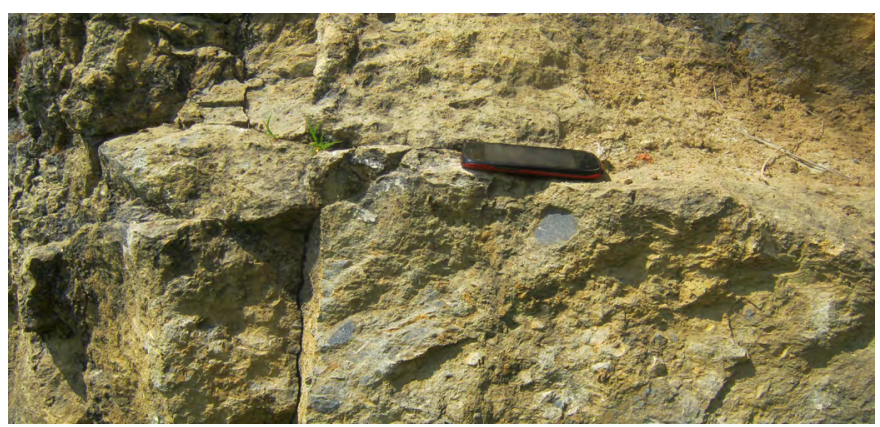

Fig. 7: Field photograph showing lithology of the Godam Formation (Upper Terrace) on the way to Godam from Kusma. The sediments are strongly cemented by calcite forming conglomerate. Clasts are angular, poorly sorted, and are made up of limestone, calcareous phyllite and calcareous quartzite. Matrix is extensively weathered forming residual soil.

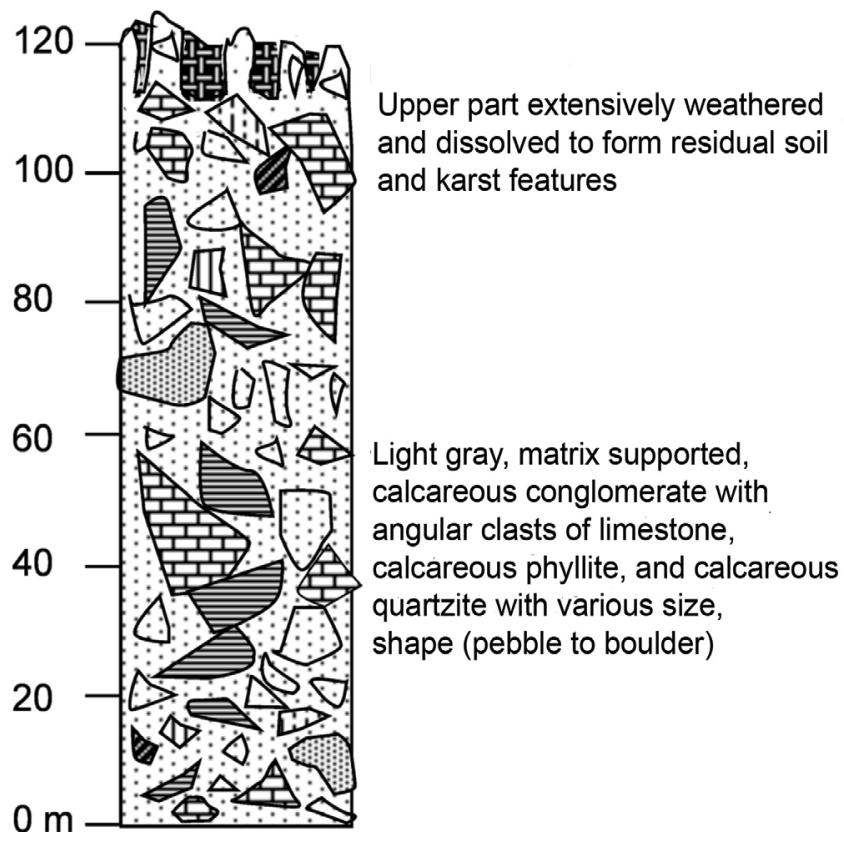

Fig. 8: Columnar section of the Badagaun Formation (Middle Terrace) at Badagaun on the way to Modibeni.

The Godam and Badagaun Formations are devoid of high-grade metamorphic rocks such as gneiss and schist, most of the clasts are made up of well-laminated calcareous shales, siliceous limestone and quartzites. It suggests that the sediments were-derived from the lower and middle parts of the Tethys Himalaya. The Modibeni Formation consists of both high-grade metamorphic rocks and sedimentary rocks suggesting a mixed source from Tethys Himalaya, Higher Himalaya and Lesser Himalaya.

\section{DISCUSSION}

The Lesser Himalayan valley-fill sediments are characterized by unique terraced landforms along the major river valleys of central Nepal Himalaya such as Kali Gandaki, Modi Khola, Seti Khola, Madi Khola (Sharma 1980). The middle and upper 


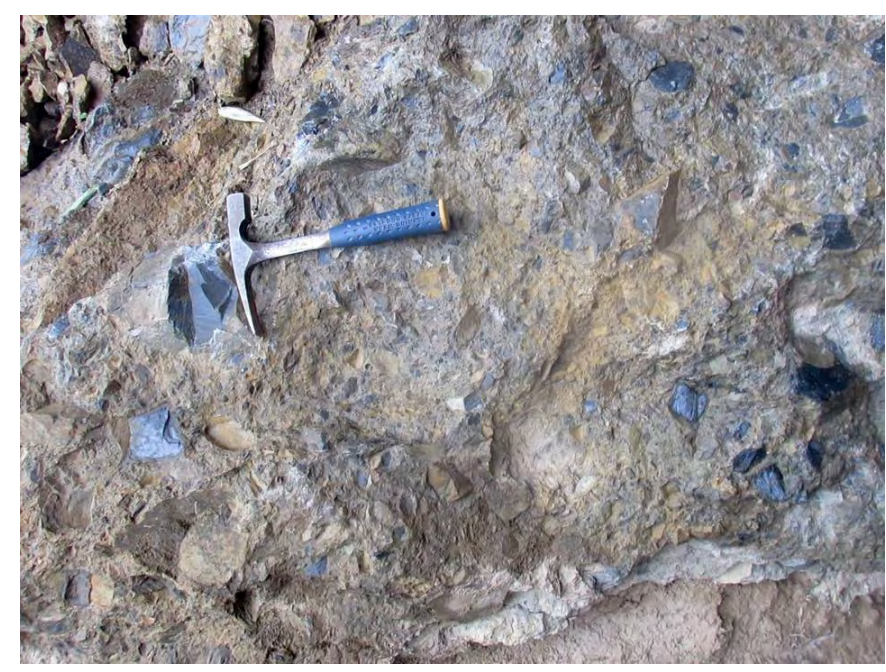

Fig. 9: Field photograph of fresh outcrop of conglomerate of the Middle Terrace seen at freshly digged foundation of a house at Kusma. The conglomerate is similar to the conglomerate of Upper Terrace.

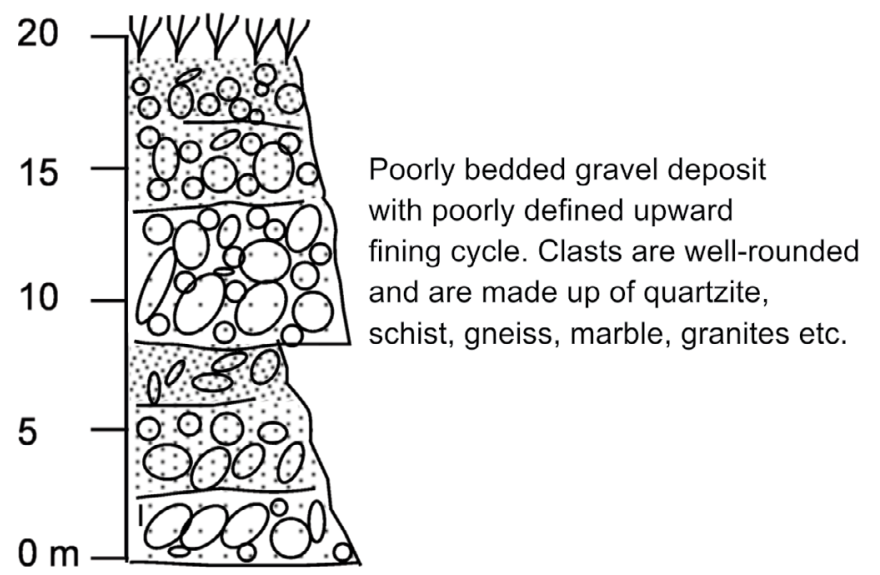

Fig. 10: Columnar section of the Modibeni Formation.

river terraces of the Modi Khola are exceptionally thick and stand up to about $400 \mathrm{~m}$ above the present river bed. The terraces express almost vertical cliffs along the Modi Khola. The aggradational terraces in the Modi Khola valley have been classified into three levels which is consistent with the classification by of the terraces by Sharma et al. (1980) and Yamanaka and Iwata (1982).

The sediments in the Middle and Upper Terraces are illsorted and layering is completly lacking. The clasts are entirely angular. Sometimes exotic angular boulders appear suddenly in the sediments. All of the evidences suggest a catastrophic event in the Quaternary time in the area. Lithology of clasts is similar to the rocks of the Tethys Himalaya. As the Tethyan rocks are exposed only in the Annapurna Range north of Annapurna Base Camp where the Modi Khola originates, the sediments must have been transported from the Annapurna Range.

Similar terraces have been identified in the Pokhara valley along the Seti River, just east of Modi Khola (Yamanaka 1982; Fort and Freytet 1983; Fort 1985; Schwanghart et al. 2014;

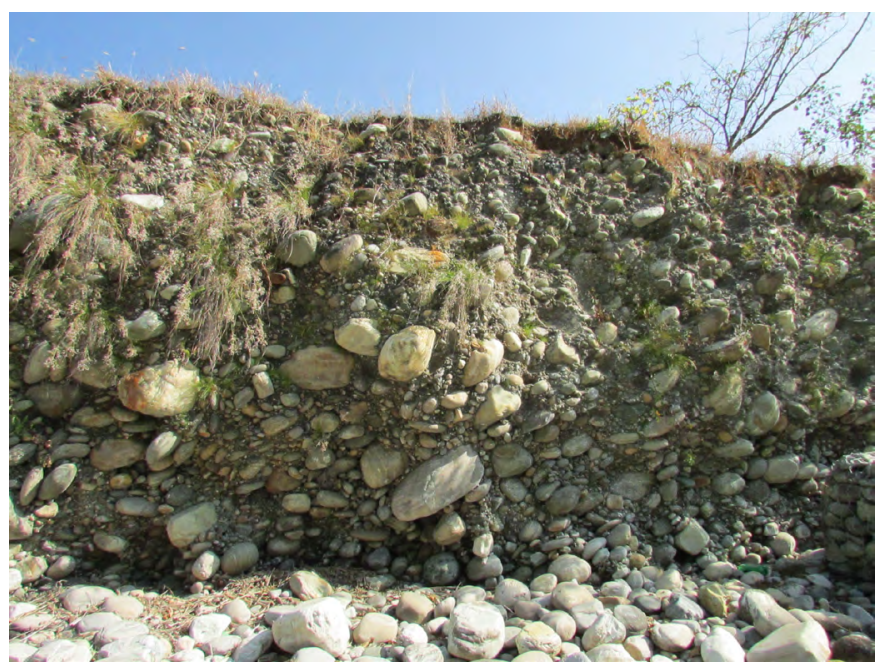

Fig. 11: Photograph of the Modibeni Formation.

Schwanghart et al. 2015). Sediment characteristics of the highest and Middle Terraces of the Seti River (i.e., Tallakot and Ghachok Formations, respectively) are similar to that of the Godam and Badagaun Formations in the present study area. The Pokhara Formation which is younger than the Tallakot and Ghachok Formations is extensively distributed in the Seti Valley. However, similar terrace is not found it the Modi Khola valley. Work of Schwanghart et al. (2015) suggest that the Pokhara Formation is the result of catastrophic fluvial aggradation and debris flows events following at least three $\mathrm{M}>8$ mega-earthquakes in 1100,1255 , and 1344 C.E. As the older terraces have also the similar sedimentological characteristics, they may also have been formed by catastrophic outbursts from natural dams or large rock-ice avalanches in the Annapurna Range triggered probably by paleo-megaearthquakes. Deep incision of the rivers along the terraces forming steep cliffs in the area is the evidence of continued neo-tectonic activity in central Himalaya.

Terrace flats arranged in three successive levels on either side of Kali Gandaki show that the region has undergone at least three periods of uplift. Probably the uplift of the terraces belong to the morphogenic phase (Holocene uplift, Gansser 1983) of the Himalayan uplift.

\section{CONCLUSIONS}

Geological investigations were carried out on the river terraces along the Modi Khola valley in west Nepal. At least three river terraces are observed along the Modi Khola valley between Gijan and Modibeni. The Upper Terrace is named as the Godam Formation, Middle Terrace is named as the Badagaun Formation and the Lower Terrace is named as the Modibeni Formation. The Upper and Middle Terraces have similar lithological and sedimentological characteristics. They are made up of very hard, deeply weathered, matrix-supported conglomerate with angular fragments of shale, laminated siliceous limestone and quartzite. Both the terraces are deeply weathered and show well-developed karstic features. The Middle Terrace is also characterized by development of many caves and sink holes in the area. Both the upper and Middle 
Terraces have been interpreted as cohesive debris flow facies derived from the Annapurna Range. The Lower Terrace (Modibeni Formation) is fluvial deposit consisting of rounded and subrounded clast-supported conglomerate. The sediment is mixture of rocks from Tethys, Higher and Lesser Himalayas. Presence of three levels of terraces indicates at least three phase of uplift in the area in the Holocene time. The debris flow deposit in the upper and Middle Terraces are probably the results of catastrophic outbursts from natural dams or large rock-ice avalanches in the Annapurna Range triggered by paleo-megaearthquakes. This is the indication of continued and prolonged neo-tectonic activity in the central Nepal Himalaya.

\section{ACKNOWLEDGEMENTS}

This work is a part of the Faculty Research Project awarded to LPP in the year 2016 by the University Grant Commission, Nepal. We thank University Grant Commission, Nepal for financial support and the Central Department of Geology, Tribhuvan University for providing laboratory and other facilities. We are grateful to Krishna Subedi for accompanying in the field.

\section{REFERENCES}

Fort, M., and Freytet, P., 1983, The Quaternary sedimentary evolution of the intramontane basin of Pokhara in relation to the Himalaya Midlands and their Hinterland (west central Nepal). In: Sinha, A. K. (Ed.), Contemporary Geoscientific Researches in the Himalaya, v. 2. pp. 91-96.

Fort, M., 1976, Quaternary deposits of the middle Kali Gandaki valley (central Nepal). Himalayan Geology, v. 6, pp. 499-507.

Fort, M., 1985, Contribution of sedimentary and geomorphic data to the knowledge of paleoclimate in Nepal Himalayas. Current Trends in Geology, vol. VI (Climate and Geology of Kashmir), Today's and Tomorrow's Printers and Publishers, New Delhi, pp. 159-189.

Gansser, A., 1983, The morphogenic phase of mountain building. In: Hsü, K. J., (Ed.), Mountain Building Processes: London, Academic Press, pp. 221-228.

Gurung, H., 1970, Geomorphology of Pokhara valley. Himalayan Review, v. II-III, pp. 37-49

Hagen, T., 1969, Report on the geological survey of Nepal. Volume 1: Preliminary econnaissance. Denkschiiften der Schweizerischen Naturforschenden Gesellschaft, Band LXXXVI/1, pp. 1-185 (with a geological map).
Hormann, K., 1974, Die Terrassen an der Seti Khola - Ein Beitrag zur Quartären Morphogenese in Zentralnepal. Erdkunde, v. 28, pp. 161-176.

Iwata, S., 1984, Geomorphology of the Thakkhola Muktinath region, central Nepal and its late Quaternary history. Geological Reports of Tokyo Metropolitan University, v. 19, pp. 25-42.

Iwata, S., and Nakata, T., 1985, River terraces and crustal movement in the area around Narayanghat, Central Nepal. Jour. Nepal Geol. Soc., v. 3, pp. 33-42.

Iwata, S., Yamanaka H., and Yoshida M., 1982, Glacial landforms and river terraces in the Thakkhola region, central Nepal. Jour. Nepal Geol. Soc., v. 2, pp. 81-94.

Jennings, J. N., 1971, Karst. Cambridge, the M.I.T. Press, 252 p.

Miall, A. D., 1978, Lithofacies types and vertical profile models in braided river deposits: A summary, in Fluvial Sedimentology, edited by A. D. Miall, Mem. Can. Soc. Petrol. Geol., v. 5, pp. 597-604.

Miall, A. D., 1996, The geology of the fluvial deposit, sedimentary facies and petroleum geology. Springer- Verlag Berlin Heideberg, $582 \mathrm{p}$.

Schwanghart, W., Bernhardt, A., Stolle, A., Hoelzmann, P., Adhikari, B. R., Andermann, C., Tofelde, S., Merchel, S., Rugel, G., Fort, M. and Oliver Korup, 2015, Repeated catastrophic valley infill following medieval earthquakes in the Nepal Himalaya. Science Express, 10.1126/science.aac9865, pp. 1-4.

Schwanghart, W., Bernhardt, A., Stolle, A., Adhikari, B. R., and Korup, O., 2014, Reassessing catastrophic infill of the Pokhara Valley, Nepal Himalaya. Geophysical Research Abstracts Vol. 16, EGU2014-15787, 2014 EGU General Assembly.

Sharma, C. K., 1975, Natural resources of Pokhara valley. Navana Printing Works Pvt. Ltd., Calcutta, 106 p.

Sharma, T., Upreti B. N., and Vashi, N. M., 1980, Kali Gandaki gravel deposits of central west Nepal-their neotectonic significance. Tectonophysics, v. 62, pp. 127-139.

Sharma, T., 1980, Origin of Quaternary deposits of Nepal and their neo-tectonic significance. The Himalayan Review, v. 12, pp. 31-43.

Upreti, B. N., 1999, An overview of the stratigraphy and tectonics of the Nepal Himalaya. Jour. Asian Earth Sci., v. 17, pp. 577-606.

Yamanaka, H., and Iwata, S., 1982, River terraces along the Middle Kali Gandaki and Marsyangdi Khola, Central Nepal. Jour. Nepal Geol. Soc., v. 2, Sp. Issue, pp. 95-111.

Yamanaka, H., 1982, Radiocarbon ages of upper Quaternary deposit in central Nepal and their geomorphological significance. The science reports of Tohoku University, $7^{\text {th }}$ Series (Geography), v., 32, No.1. pp. 46-60. 